\title{
LETENYEI LÁSZLÓ: TELEPÜLÉSKUTATÁS
}

\section{LETENYEI LÁSZLÓ (szerk.): TELEPÜLÉSKUTATÁS SZÖVEGGYÜJTEMÉNY}

A tanulmánykötet szerzöi: Csernák Boldizsár, Eranus Eliza, Futó Péter, Garamhegyi Ábel, Heltai Erzsébet, Kürtösi Zsófia, Láng Sarolta, Letenyei László, Máth András, José Luis Molina, Rácz Attila, Pálinkó Éva, Sarah Pink, Teresa San Román, Szántó Zoltán. Szanyi Ágnes, Szathmári Milán, Szeszler Zsuzsa, Tarjányi József, Tompai Géza, Vicsek Lilla, Varga-Ötvös Béla, Vörös Miklós, és a fordítók: Erdödi Katalin, Földházi Erzsébet, Kállai Tibor.

\section{(Kézikönyv és tanulmánygyüjtemény. Ráció Kiadó és L' Harmattan, Budapest, 2005, két kötet összesen 728 o.)}

\section{NIKITSCHER PÉTER}

Napjainkban a telepuilések, térségek jövöjére vonatkozó döntések meghozatalakor egyre fontosabb szerepet játszik a „társadalmi egyeztetés”, a helyben élő emberek véleménye. A helyi szándékok, vélemények feltárására azonban nincs egységes módszertan. A szóban forgó könyv által ,településkutatásnak” nevezett módszerek több tudományterülethez is szervesen kapcsolódnak, hiszen a települések életével, fejlődésével, belső struktúrájával a szociológiai, közgazdasági, földrajzi vagy antropológiai kutatások egyaránt foglalkoznak.

Egyre több társadalomtudományi irányultságú egyetemi képzés vesz fel tanrendjébe településkutatással kapcsolatos kurzusokat. Ennek ellenére ezidáig kevés olyan munka állt az érdeklődők, a kutatók vagy a diákok rendelkezésére, amely alapos elméleti és gyakorlati útmutatót adna a településkutatás módszertani kérdéseiröl. Ezért örvendetes a Letenyei László által írt és szerkesztett, két kötetes „Településkutatás" címü munka megjelenése. A kétkötetes kézikönyv és tanulmánygyüjtemény a Szerzỏ megfogalmazása szerint elsősorban a település vagy területfejlesztés területén dolgozó szakemberek, valamint a társadalomtudományi szakos hallgatók számára készült, de a téma iránt érdeklődők számára is érthető és érdekfeszítő olvasmányt jelent.

A kötetben bemutatásra kerülő módszerek kiválasztásakor a Szerző a hiánypótlás nem titkolt szándékával járt el, olyan módszereket választva, amelyekrôl magyarul egyáltalán nem vagy csak kevés irodalom áll rendelkezésre, ilyenek például az alábbiakban részletesebben is ismertetett mentális térképezésröl, kapcsolatháló elemzésról vagy a fókuszcsoportos vizsgálatról szóló fejezetek. 
A szerző azon véleményét, hogy ,a mindennapi élet nincs tekintettel a diszciplináris határokra" tükrözi a kiválasztott módszerek interdiszciplinaritása. Letenyei Lászłó szerint az egyes települések, térségek életének valós megismerése csak tudományközi megközelítéssel lehetséges, ami azonban némi távolságtartást tesz szükségessé az egyes tudományok belsó kategóriáitól, szakzsargonjától, ennek is köszönhető, hogy a kötet nyelvezete viszonylag egyszerü, és az egyes fejezetek az eltérő szakirányú olvasók számára is érthetők.

A kétkötetes munka első kötete tankönyv és kézikönyv, második kötete pedig szöveggyüjtemény, amely a tankönyv egyes fejezeteiben tárgyalt témákhoz kapcsolódó hazai vagy külföldi szerzők szövegeit tartalmazza, amelyek közül egy kivételével mind most jelenik meg magyar nyelven elöször.

A tankönyv fejezetei gyakorlati szempontból mutatják be a különbözö, a településkutatás során használható társadalomtudományi kutatási módszerek elméletét és alkalmazását. Az egyes módszerek elsajátítását megkönnyítendö a kötet végén minden fejezethez ellenőrző kérdések és gyakorlatok is kapcsolódnak.

A kötet tartalmilag az alábbiak szerint épül fel:

Az első fejezetben a Szerzö azzal a kérdéssel foglalkozik, hogy mikor és hogyan van értelme egy településen társadalomtudományi kutatásba belekezdeni, és ezen kutatásoknak milyen szerepe lehet a későbbi településfejlesztési koncepció kialakításában. A szöveggyüjteményben az elsỏ fejezethez kapcsolódóan az Európa Tanács 1999/1260 rendelete olvasható, amely az Európai Unió térségfejlesztéssel kapcsolatos alapelveit ismerteti. Majd ehhez kapcsolódva Futó Péter és Szeszler Zsuzsa A településfejlesztési koncepció készítésének módszerei az EU-ban és Magyarországon címü írása ismerteti meg az olvasót a telepuilésfejlesztési koncepció készítésének alapjaival.

A második fejezet a Kvalitativ és kvantitatív adatgyüjtési technikák ötvözése címmel e két eltérő szemléletü kutatási gyakorlattal foglalkozik. A Szerző véleménye szerint e két adatgyüjtési technika között nem lehet és nem szabad értékbeli megkülönböztetést tenni, hiszen a helyi társadalom megismeréséhez mindkét technika alkalmazásán keresztül vezet az út. A szöveggyüjteményben ezen témához kapcsolódóan két tétel olvasható. Az első Teresa San Román A megéréstöl a megerösítésig: a terepmunka az antropológiában címü cikke, Alan Bryman szociológus pedig a kvalitatív és kvantitatív módszerek összekapcsolásáról ír.

A tankönyv harmadik fejezetével megkezdődik a konkrét kutatási módszerek ismertetése. A fejezetben az elsősorban a kulturális antropológiában alkalmazott résztvevő megfigyeléssel ismerkedhetünk meg. A résztvevő megfigyelés a kulturális antropológiai kutatás klasszikus módszere, amely során a közösség életét az abban való részvétellel, a közösséggel való együttélés során ismerheti meg a kutató. A szöveggyüjtemény idevágó fejezetében Vörös Miklós és Frida Balázs az antropológiai résztvevő megfigyelés történetét bemutató írása után a kulturális antropológia egyik klasszikusának Bronislaw Malinowskinak 1922-ben megjelent mủvének bevezetöje Vörös Miklós fordításában olvasható.

A negyedik fejezet a fókuszcsoportos interjú módszerét mutatja be. A módszer a piac- és marketingkutatás kedvelt technikája, amely során a kutató a csoport tagjaival 
folyamatos interakcióban maradva irányított beszélgetést folytatva szerzi meg információit. A Szerző véleménye szerint a fókuszcsoportos interjú módszere a településkutatásban is használható adatgyüjtési technika. A szöveggyưjteményben a módszerrel kapcsolatban három szöveg található. Elsőként Robert $K$. Merton, Marjorie Fiske és Patrícia L. Kendall A fókuszált interjú címü munkájából olvashatunk részleteket. A mú a fókuszcsoportos kutatás alapmüvének számít. Másodikként Jenny Kitzinger Bevezetés a fókuszcsoportos vizsgálatba címú munkájával ismerkedhetünk meg, amely egy, az egészségügy területén végzett kutatás példáján keresztül mutatja be a módszer alkalmazását. A harmadik szöveg a fiatal magyar kutató, Vicsek Lilla tollából származik, és a fókuszcsoportos vizsgálat kimenetelét befolyásoló tényezökkel foglalkozik.

$\mathrm{Az}$ ötödik fejezet az Interjú, kérdöív és adatbázisok gyüjtése - terepközeli módon címet viseli. A fejezetben a Szerzőnek nem célja a társadalomtudományos interjúzás, kérdőívezés alaptechnikáinak ismertetése, hisz ezekről már meglehetősen sok magyar nyelvü irodalom áll a diákok és kutatók rendelkezésére. A fejezetet inkább egyfajta kiegészítésnek szánja arról, hogyan lehet a „kvantitatív technikákat terepközeli módon" alkalmazni, valamint arról, hogy a címben szereplö módszerek miként alkalmazhatók a kötetnek címet adó telepưléskutatásban. A szöveggyüjteményben a témához kapcsolódóan Heltai Erzsébet és Tarjányi József cikkét olvashatjuk, amely az ún. mélyinterjú módszerét és annak buktatóit, a módszer alkalmazása során elkövethetö hibákat mutatja be. A másik idevágó írás Eranus Eliza, Láng Sarolta, Máth András és Rácz Attila munkája, amely a kérdőíves adatfelvétel újabb módszereivel a telefonos, számítógéppel támogatott és internetes adatgyüjtés technikáival ismerteti meg az olvasót.

A hatodik fejezet témája egy, a hazai társadalomtudományi kutatásban csak kevéssé alkalmazott módszer, a mentális térképezés. A módszer egy adott településröl vagy térségröl az emberek fejében meglévő szubjektív elképzelések, érzelmi attitúdök, információk összegyüjtésével és interpretálásával válhat a településkutatás alkalmazott módszerévé. A tankönyvben megismerkedhetünk a mentális térképezés elméletével és gyakorlatával, a szöveggyújteményben a témához kapcsolódva Roger M. Downs és David Stea Térképek az elmében címü munkájából olvashatunk egy részletet, majd a hazai kutatási gyakorlatból ismerkedhetünk meg Bíró $A$. Zoltán, Csernák Boldizsár, Garamhegyi Ábel, Letenyei László munkáival.

A hetedik fejezet a kapcsolatháló elemzés, e napjaink társadalomtudományi kutatásában oly divatos módszer a településkutatásban történö alkalmazásának lehetőségeit taglalja. A szöveggyüjteményben Szántó Zoltán a kapcsolatháló elemzés elméletével és Kürtösi Zsófia a kapcsolatháló-elemzés módszertani alapjaival foglalkozó írásai olvashatók.

A nyolcadik és egyben utolsó fejezet, a társadalomtudományi kutatás utolsó fázisával, a különbözö kutatási módszerek alkalmazásával összegyüjtött adatok, információk interpretálásával foglalkozik. A tervezési, fejlesztési célból végzett településkutatás eredményeit és az eredmények alapján megfogalmazott javaslatokat, a kutatóknak, az olvasók számára is érthető módon kell megfogalmaznia. A Szerző felhívja a 
figyelmet a kutatási eredmények alkalmazása során a monitoring fontosságára is. A szöveggyủjteményben a kutatási eredmények interpretációjával kapcsolatban olvashatunk megszívlelendö gondolatokat Deirde N. McCloskey és Sarah Pink tollából.

Az egyes fejezetekben bemutatott módszerekkel való elmélyültebb megismerkedéshez a szöveggyüjteményen kívül, a kötet végén található tematikus szakirodalmi útmutató ad irányt, amely rövid recenziókat tartalmaz az egyes ajánlott irodalmakról és internet oldalakról, ezzel is megkönnyítve a választást és a továbbhaladást.

Összességében egy nagy szakmai körültekintéssel, igényesen megirt és megszerkesztett mủröl van szó, amely mindenképpen hiánypótló jellegü és a társadalomtudományi szakos egyetemi hallgatókon kívül a témával foglalkozó számos tudományterületen dolgozó szakember is nagy haszonnal forgathatja. 